\title{
Travel Narrative and the Esthetics of Non-disclosure in Lorrain's La Dame turque
}

\author{
Robert Ziegler \\ Montana Tech, Butte
}

\begin{abstract}
uthor of fictions "studded with situations and settings that properly Amay be attributed to the category of travel and dépaysement" (McLendon, "Travel..." 13), the infamous Jean Lorrain - trafficker in scandal, terror of Parisian journalism, "incarnation of le péril mauve" (McLendon, "Communities..." 7) - has also been recognized for the elegant records of his literary voyages. Fascinated by disguises, cosmetics, pseudonyms, and masks, Lorrain fled the suffocating landscapes of familiar selves in order to embark for Valencia, Biskra, or Venice, where he searched for material with which to assemble new fictions of identity. Like a gangplank bridging his euphemized recollections of the past and dreamy suppositions about countries read of yet unvisited, the instance $d u$ départ is a privileged feature in Lorrain's writing, wiping clean the page he covered with the account of previous disappointments.
\end{abstract}

As the integrity of the exotic depends on its indescribability, Lorrain's travel narratives thematize their meandering lack of closure, their semiotic dereliction, and veiled, elusive pointlessness. As a writer who complained "mon véritable mal ... c'est de n'être pas ailleurs,"1 Lorrain preferred dismantling known realities to experiencing new ones. Epistemological evasions, his travelogues romanticize unreachable destinations, ponder the inscrutable faces of fellow travelers, and accuse the inadequacy of 
language to capture ephemeral sensations. As they sail into oblivion, Lorrain's phantom textual vessels convey the evocative emptiness of what is mourned for and unlived, suggest the rich incommunicability of missed encounters and lost chances. Like his heroines' names, his titles personalize a pleasurable nostalgia: "mon nom [est] aurait pu être, je me nomme Trop Tard, Jamais Plus, Adieu" (La Dame turque, 105). ${ }^{2}$

Consistent with the prevalent Symbolist esthetic of the era, Lorrain's discourse often celebrates its expressive limitations, exalts the unwritable as the only subject worthy of its practice. An esthete in the manner of Sir Thomas Welcome in Monsieur de Phocas, Lorrain regarded "[l]e monde extérieur" as "une source de joies inaltérables et d'autant plus parfaites que notre être en est le seul miroir" (207). Yet the catoptromantic power of the mirror is the strongest when it is empty, facing nothing, reflecting sights as yet unseen. The inconclusiveness of the itinerary that is traced in Lorrain's writing is conveyed by his reluctance to elucidate a mystery. Exotic lands whose hazy coasts are glimpsed by Lorrain's narrator are most attractive when they again dissolve into grey invisibility.

The peripatetic Lorrain observed the world through the lens of others' writing and was more convinced by Gautier's textual Spain than by the Spain to which he travelled. ${ }^{3} \mathrm{His}$ view of foreign lands was preconditioned by his readings, which discouraged him from testing books against experienced reality. Underlying Lorrain's travel works is a self-defeating hermeneutic, a refusal to impoverish imagined life by actually living it. Corsica and Egypt are only secondary references to the countries toured initially in his journey through the library. ${ }^{4}$ Thus, the paradox that immediate, first-hand knowledge of a place is less meaningful and direct than prior textual mediation makes Lorrain disinclined to read the countries he explored, a writer who withheld the keys to interpreting his stories. Meta-narratives whose subject is enshrouded in uncertainty, his texts become the lands to which our access is forbidden, exotic sites best apprehended in elusive lines of text.

Lorrain's writing extends the tradition of Romantic travel narrative, as "la littérature ... fixe ... au voyage son objet et sa finalité, en même 
temps que la figure du voyageur se confond ... avec celle de l'écrivain" (Le Huenen, 51). Yet as this paper argues, Lorrain's book inverts the purpose of the journey, makes the experience of dépaysement a re-exposure to oneself. Modeled on the voyage, the solipsistic act of reading lifts anchor, allows a backward glance at the country of the known, while circumnavigating experience that halts the journey of discovery, whose purpose is to carry on and afford discovery of nothing.

La Dame turque (1898), which tells of Lorrain's trip to Malta with his mother, is a record "qui nous valut une nouvelle très proche de Pierre Loti" (Jullian, 257). The text shows travel's purpose as blocking disenchanting knowledge, ensuring the permanent disorientation of the wayfaring escapist, and preventing him from experiencing the events his work describes. Whereas "[e]tymolgy tells us that the narrator is the one who knows, "5 making the narratee's reason for listening "the prospect of acquiring 'information'" (Chambers, 50), the success of Lorrain's narrative depends instead on non-disclosure. Indeed, the book is a transcription of what is "nevermore," "too late," a speculative reconstruction of the things "that might have been." Departing from dry land where personal history had intruded, unmoored from the requirement of accommodating others, the text takes to the sea whose anarchic unreadability suspends interpretation until the work arrives in port. Experience foregone becomes the stuff of retrospection, a suppositional adventure that Lorrain only could imagine. The muteness and inactivity of the traveler in transit enable him to fictionalize events that never happened. Experiential silence turns into literary discourse; doing nothing permits the narrator to describe the things he might have done. From his position at the handrail on the deck of Lorrain's story, the teller speaks rhapsodically of what will vanish in a moment: "fantasmagorie des départs, Tripoli pour nos adieux s'était faite belle" (16).

Significantly the novel tells of failed communication, of the evils of translation, of avoided contact with another. A passenger on board the Asia, the narrator flees the here and now, a barren land that flowers only when it recedes into the distance. By romanticizing the "délicieuses mortes 
un instant ressuscitées" (18), Lorrain's novel introduces a necrophilic temporality, by killing what is living to restore it as a memory.

The story is a meditation on the mysterious dame turque, a voyager who, with her retinue of servants and a translator, accompanies the narrator on his four-day trip to Malta, where rendez-vous are missed, conversations misconstrued, confidences unshared, and mementoes unexchanged. A special meaning is attached to the experience of the passager, both as the provisory individual whose identity is fleeting and to the ephemerality of the happenings that are witnessed by the tourist. Rarefied as the diffuseness of an anamnestic vapor, the dame turque is evoked as "le parfum de tout ce long voyage" (16), as a memory trace dispersed into the novel's tangy air. Mystery and perfume, recollection and melancholy, she is exiled from the present, often shunned by the narrator, so that she may undertake a journey that brings her back as Lorrain's story. More beautiful and enduring than the places left behind are the mortal moments contemplated from the perspective of their passing hours "déjà nostalgiques et irréparables, hélas!" (18). Recovering the transitory, bringing back the irretrievable may be the goal of Lorrain's textual resuscitation of the dead. Instead of serving as a cenotaph that memorializes emptiness, the book becomes a figure for the vagrancy it celebrates.

Topologically expressing the novel's shifting meaning is the boundless ocean setting for the magical encounter. On the deck amidst the waves, the graceful "étrangère" appears, diffused into the chastely blurring fog of cigarettes, a hazy, drugging vision born of hookah-smoking reverie. Lorrain's narrator is the model for the unperceiving reader, who cannot see through veils, closed trunks, cannot fathom unknown languages. The Islamic woman's diffidence before the prying eyes of infidels is respected by the text, which asks no questions, discloses little. And when the narrator enjoys a chance to look beneath their surface, at the curving lips and blue-grey eyes of the woman who bewitches him, he himself erects a barrier to knowledge and perception, as he compares her to an actress whose stylized traits become a "masque" (27). 
Wondering at the violation of the fasting rules of Ramadan, the indulgence in tobacco by a follower of Allah, the narrator learns that, once at sea, the faithful are exempted, and so enjoy unstructured freedom: "la mer remueuse n'est à personne" (26). What the voyager escapes from is a land-locked culture's strictures, its repetitious idioms, and confining, stale conventions. The lawlessness of the ocean lifts the taboos of religion, the injunctions of society that define behavior and mold character. On a ship, there are no nationalities, no temples, codes, or grammars, no institutions decreeing how identities congeal. Passengers are different from the spectacle they witness: of harpooned giant tortoises turned over on their backs, immobilized in their carapaces, churning the air with helpless legs (25).

Seafaring disponibilité means forever being nowhere, knowing nothing that would define the self vis-à-vis another person. On the second day, the narrator finds the woman with her entourage sprawled out upon the bridge, her haggard face turned pale from seasickness. Huddled in the company of other livid, prostrate sufferers, vulnerable "au milieu de toutes ces promiscuités" (38), she is readable by the narrator until their gazes interlock, whereupon she disappears behind a wall of colored cloth that is set up by her servants to guard their mistress's threatened modesty. Chivalrous, discreet, the narrator retreats, his eyes downcast, reabsorbed in his examination of the island that approaches. "Ile de chimères et de mirages" (46), the distant land becomes the object of the displaced sensual fantasies that were directed at the woman. As her whiteness is assimilated to minarets' "old ivory" her isolation like Malta's "dans son immense ceinture de vagues" (47), he projects his sense of gallantry onto the "île des Chevaliers," a timeless place inviting pleasurably interminable reveries.

His associative stream of thought allows the site to be personified, as he envelops place and person in a tide of speculation. Like the city, his hypotheses are mortuary constructs, art works that are beautiful when they are lifeless and completed. Malta, says the narrator, is both a building site and graveyard, a necropolis created from the material it quarries 
(47). The unknown is a mine from which conjecture is extracted, with which theories can be fashioned as dead monuments to certainty.

The identification of the island and the woman is made clear when the reader learns her name at the time the travelers disembark. Then the vitality of guesswork yields to the morbidity of knowledge, to the provision of explanations which becomes a impoverishing exercise. Privacy is violated, the door of mystery forced open, when all passengers are subjected to inspection by Maltese doctors. Officials charged with checking for the spread of typhoid fever board the ship and profane the empty textual space of silence as they feel the woman's pulse, look at her tongue, and read her name. Yet like the haîck which, when lifted, reveals a stylized mask beneath it, this onomastic indiscretion makes the woman's secret deeper. Shiamé Esmerli, a strand of liquid syllables, is less a sound pronounced with open mouth than a kiss bestowed when lips are sealed. Disclosure becomes a confidence that is whispered to the narrator, a sound of clicking pearls that is luxuriously meaningless: "Comme elle est pâle et languissante ..., la mystérieuse dame turque ... bien plus mystérieuse encore, maintenant que je sais son nom" (56). As material that is utilized by the self-mystifying narrator, the woman's name is nothing but a strange phonetic ornament, not an identity that infringes on his prerogative to interpret, but a defamiliarizing barrier, another veil or unknown language. ${ }^{6}$ The xenophilic text restores the woman's anonymity, its title an evocation of her enigmatic origins. Representative of a people that is seductively unreadable, she is relieved of her identity and becomes her reader's empty vessel. As the portable decor for Lorrain's migratory narrative, she triggers a sense of dépaysement wherever she appears. For the traveler desirous of what is different and unrecognized, the dame turque is an instrument that restores the unfamiliar, an estranging backdrop against which every sight seems fresh and striking. Uncluttered by information about her origins and history, she is an unfamiliar landscape inviting the traveler to visit.

It is only by implication that the narrator acknowledges the woman as the atmosphere of his retrospective story. Making the narratorconsumers' hands the place the novel docks, he withholds interpretation, 
solicits readers' intervention, sells a mystery unencumbered by explanatory detail. Unlike vacationers who bore their guests with excruciating details, graphic visual records of their activities as tourists, Lorrain knows to give his text a deliberate indistinctness that invites collaboration to flesh out what had been sketched. The narrative is targeted at place-bound story-purchasers, whose reading is the paid-for journey they embark on from their chairs. As Shiamé is a mystery which the narrator acquires and then hands to an audience as the tale they tell themselves, their understanding - spatialized as the trip by which they reach it - subverts the discursive practice by which the narrator makes money.

This trafficking in narrative brings up the secondary issue of the antiSemitic sentiment that distinguishes the storyteller. Little has been written on Lorrain's anti-Jewish feelings, and a political reading of his work is beyond this essay's scope. Yet the writer who professed "une sorte d'anarchisme de droite," a bigotry "qui le plaça parmi les antidreyfusards" (Jullian, 221) linked his antipathy for Jews to a view of creativity as a usurious estheticism that degraded literature into business. For Lorrain, Jews saw mystery as an asset to be liquidated, exchanged for the vulgarity of unwanted information. The preciousness of the silence with which the dame turque is enveloped becomes the currency of language into which her resource is dispersed. It is the Armenian Jewish translator who depreciates the narrative, whose mediation cheapens the knowledge from which he seeks to profit. The narrative act that Lorrain's text refrains from re-enacting impoverishes both the mystery in the process of explaining it and the listener who reimburses his contemptible intermediary. Caricatured as the sycophantic, unctuous materialist, Shiamé's interpreter exchanges dismal facts for cash, as he reveals where she is lodging and holds his hand out for a tip. The narrator, before adrift in pleasant speculation, a homeless reader unmoored from immobilizing certainties, must fix his wayward reverie at a specified address, within the claustrophobic hotel walls of unsolicited disclosure.

Contrasting with the images of impenetrability and secrecy is the image of the grasping Jew with open mouth and hands. The novel seeks 
to compensate for the latter's indiscretion by economizing information, telling less and telling better. The narrative transaction that is proposed by the interpreter is redefined by the storyteller, who devalues the explicit and commodifies the ambiguity that he had prized himself. That the theme of travel models the indecision of the reader, capsized on an open sea of hermeneutic options, does not change the fact that the Jewdespising teller of the story also trades in the material that his hated source provides. In repeating the same gesture, he also offers us his volume and then extends a servile hand in expectation of his payment. The only difference is that the narrator seeks to fuel our speculation, inflating information's price by limiting supply.

Unlike the fawning open-handedness of the beggarly interpreter is the eloquently silent greeting described by his employer. The hand with which she touches her forehead, heart and lips ("à toi ma tête, à toi mon coeur, à toi mes lèvres" [64]) is a gestural reminder that she in fact is giving nothing. The hand held to the lips "qui semble envoyer [un] baiser" (64) recalls the moistly whispered osculation of her name. Yet the woman's salutation may promote a greater closeness paradoxically by reemphasizing her unreadability as a subject. By equating intimation with a spurious form of intimacy, Lorrain's novel coyly veils what is ineffably suggestive, covers the modest Shiamé in clothes of ornamental vagueness. It is the Jew who rends the fabric and translates the unspoken, exposing the naked commonness of his mistress's ideas. It is his speech that most imperils the subsequent account as he dissipates the mystery with his acquisitive prolixity. What the interpreter makes plain is what the narrator would hint at, so that the histoire gains in substance as the récit loses beauty.

The lachrymose interpreter relates the woman's tragic story: of a husband in disgrace, his being exiled to the desert, the inconsolable spouse's efforts to rejoin the banished pasha - a meandering story paralleling the woman's pointless journey. A displaced second wife, who is nomadic, disinherited, she is the depreciated subject of a second-hand narrative. The unintelligibilty of Turkish is cashed in for broken French by a translator who sees his speech as a form of merchandise, what Barthes 
has called "monnaie d'échange, objet de contrat" (95). Indeed, the content of the narrative concerns another proposed transaction whereby the elusive woman, treasured as a fleeting apparition, would barter chattel, slaves - her encumbering impedimenta - for the narrator's agreement to accompany her to Paris. As the value of the travelogue lies in the desertion of its subject, recreating the gap that separates the traveler and destination, it is the art of retrospection that allows the distance to be closed. Thus, if Shiamé were brought back as a travel souvenir, her presence would inhibit the esthetic work of recollection.

Untold, the woman's story had been assessed in terms of literature, as yielding readers the pleasure of unconfirmable hypotheses. Only narration subjects the tale to critical appraisal, to a cynical evaluation of its limiting truth value. No matter how seductive is the dame turque as a subject ("je voulais croire à la véracité du récit," claims Lorrain's spokesman), the "atmosphère de brocantage" (81) that her translator emits discredits what he says and pollutes the mind with incredulity. Lorrain's storyteller, an unacknowledged shopper for material, projects his own commercial needs onto the Jewish brocanteur. What was exotically evocative, unspecific, evanescent becomes the merchandise devalued by a glut of information.

Henceforth the narrator tries to shun both tale and raconteur, the mystery's solution given by the loathsome "mercanti" (82). The recurrent theme of diminishment and of inequitable exchanges again appears when the Jew suggests a symbolic swap of rings - of the narrator's star sapphire for Shiamé's dull opal, a jewel described as lacking any mystery or sparkle, lusterless, devoid of rainbow fire within its depths. Crude and flatly evident like its now uninspiring wearer, the opal is alleged to bring bad luck to Europeans, while in Asia it is a symbol of devotion, says the translator: "c'est la pierre de l'abnégation et de l'amour sans même espoir de retour, c'est le signe de l'esclavage, la pierre nuptiale entre toutes" (127). Establishing a baneful bond of subservient abjection, the proposed exchange of rings would wed the teller to his subject, would charge the master-narrator with responsibility for his text. So while condemning Shiamé to resume a life of endless travel, he takes the fateful token that 
requires his devotion, that subjects him to the malediction of narrative veracity. In keeping with his inclination to pay to be told nothing, the narrator accepts the jewel to be rid of the translator, defraying the expenses for his passage on the ship. Two hundred francs dispose of the importunate informant, who is metonymically replaced by "un souvenir de sa maîtresse" (103). So while the narrator's first object was the acquisition of a story, a fading, scented memory of rice powder and jasmine, what he seeks is the prerogative to dispose of his own narrative, a tale that will entitle him to speak or else say nothing.

The last exchange occurring between the dame turque and the storyteller annuls the prior marriage of disclosure to narration, as the opal passes back into its grieving owner's hand, whose fingers slowly open and drop the ring into the sea. The gesture with which the novel ends is not of grasping apprehension, but of relinquishment implying disconnection and abandonment. As the narrator's acquaintance with the dame turque had grown closer, she had forfeited the vitality that her mystery imparted, had been circumscribed by explanation and estheticized to death. The attractiveness and promise of the veiled insaisissable had been enshrined in static imagery as art's finished, deathly handiwork. Like the madonnas seen on the corners of the streets of La Vallette, stone forms dressed in faded silk and crowns made of dried roses, Shiamé was locked inside a reliquary narrative, was a "deliciously dead" hour from which recollection sailed away. Her hidden face and restless features that were borne on moving ships were fixed by understanding, set against a stable backdrop, "tel un portrait dans son cadre" with Malta's port the "toile de fond" (118). Like the island-city built with the materials undermining it, she is proleptically transformed into a beautiful cadaver, a mannequin of wax inside a gallery of memories. Incapable of speaking or of altering her story, she is "déjà marquée de l'irréparable sceau de celles qui vont partir" (118). Thus, the voyage charts the evolution of experience into narrative, changing people into statuary, chronicles into fictions, description into ellipsis, and texts into their readings. 
In the travel literature dating from the Renaissance to the Enlightenment, documented visits to exotic, strange locales had emphasized the accuracy and directness of reporting. As Le Huenen writes, there had existed then "une relation apodictique entre la simplicité du style et l'expression de la vérité" (47). It was its narrative authority that the document established, since "[c]'est par la description que le savoir circule dans le texte" (Le Huenen, 49). Conversely, the Romantics stressed the literarity of their chronicles, as consuming antecedent works supplied the impulse for their journeys, which were added as new readings of the texts of foreign lands. "Désormais le récit devient la condition première du voyage au lieu d'en être la résultante ou l'une de ses possible conséquences" (Le Huenen, 51). No longer was the goal to share information with an audience but to withhold it so they undertook an imaginary voyage. What circulates in Lorrain's work is not knowledgebased description, but a reluctance to know anything that would curtail his narration. If the travelers' experience is one of perfect, lovely places, if what they see is art already, creativity becomes redundant. The preliminarily explained enigma of the mysterious dame turque is like Georges Sand's view of nature as encountered in Majorca: "une de ces vues qui accablent parce qu'elles ne laissent rien ... à imaginer" (128). Instead of passing on reports of an unfamiliar country, one recreates the silence in which the narrative is grounded, makes readers fill the lacunae in, and explore the geography of their minds. The fading of a distant coast into the line of the horizon, "l'effacement du référent mondain" (Le Huenen 51) is the veil put on a face. The narrator's reluctance to discharge his role as reader shows him eclipsed behind a mystery he lets his audience interpret. Different from the stridency of explanatory speech is the commercial inexplicitness of self-abnegating narrative.

Faithless to the story whose factuality he spurns, he returns the ring of truth which then is thrown into the ocean. Uncompassed by information, freed from restrictive ties of evidence, Lorrain's novel, having set forth from the sources that inspired it, again takes to an open sea of conjecture and uncertainty, before arriving in its readers' hands as its different ports of call. Emptied of its cargo of specificity and detail, it 
is a vessel charged with the ambiguity that it brings back and distributes. A literary corollary of a subject undescribed, Lorrain's novel also poses as an unfamiliar topos. Yet its unsignifying vacancy, which accommodates all readings, only encourages what Holland calls a "re-creation of ... identity" (818). If its pages' unmapped territory seems to beckon gypsyreaders, offering the illusion of interpretive mobility, it ultimately returns them to a landscape seen too often, by ensconcing them in the reassuring harbor of the self.

\section{Notes}

${ }^{1}$ Quoted from an unpublished letter in McLendon, "Travel as Hunger Urge...," 15.

'Ellen, heroine of Lorrain's novel of the same name, describes herself by using the same verse from Dante Gabriel Rosetti. See Ellen, 114.

3See Lorrain's collection of travel sketches of Spain included in Un Démoniaque (1895).

${ }^{4}$ In the travel narratives of the Romantics, the "intertexte de l'Itinéraire est immense, les sources sont abondantes, les citations s'y multiplient. Le récit n'échappe pas toujours à la compilation, et le vécu du voyageur cède rapidement le pas à l'étalage de sa bibliothèque ..." (Le Huenen 54).

${ }^{5}$ Chambers cites the Oxford English Dictionary to relate the Latin narrare to gnarus, meaning knowing, skilled (70).

${ }^{6}$ Among Lorrain's contemporaries, writes McLendon, the "very novelty of strange latitudes and exotic climes seems to generate the onomastic excesses of many a traveler's account, whether in simple conversation, in prose or in verse. We can recall Mérimée's scathing parody in le Vase étrusque of the Parisian dandy who has just returned from a trip to Egypt and can utter scarcely ten words of French without dropping in a yatagan, a metchlâ, or a hhaïck" ("Hunger as Travel Urge...," 18).

${ }^{7}$ As Sir Thomas Welcome affirms: "Les choses du passé sont déjà mortes; pourquoi s'attarder sur un cadavre? Chaque chose possédée est déjà une pourriture, et quand nous regrettons une chose, c'est déjà un germe de mort que nous portons en nous" (Monsieur de Phocas, 290-1). 


\section{Works Cited}

Barthes, Roland. S/Z. Paris: Éditions du Seuil, 1970.

Chambers, Ross. Story and Situation: Narrative Seduction and the Power of Fiction Minneapolis: University of Minnesota Press, 1970.

Jullian, Philippe. Jean Lorrain ou le Satiricon 1900. Paris: Fayard, 1974.

Kyria, Pierre. Jean Lorrain. Paris: Seghers, 1973.

Le Huenen, Roland. "Le Récit de Voyage: L'Entrée en littérature." Études Littéraires 20.1 (Spring-Summer 1987): 45-61.

Holland, Norman. "UNITY IDENTITY TEXT SELF." PMLA 90 (1975): 813-22.

Lorrain, Jean. La Dame Turque. Paris: Per Lamm, 1898.

. Ellen. Paris: Douville, 1906.

. Monsieur de Phocas, Astarte. Paris: Livre de Poche, 1973.

McLendon, Will. "Communities of Vice and Despair in Jean Lorrain's Fiction." Perspectives on Contemporary Literature 3.1 (1977): 7-14.

. "Travel as Hunger Urge in the Works of Jean Lorrain." South Central Bulletin 2.1 (Spring 1985): 13-24.

Sand, Georges. Un hiver à Majorque. Paris: Livre de Poche, 1984. 